\title{
Hydro-chemical and microbial assessments of water resources around cassava mills in a sedimentary formation of Ilaro, Southwest Nigeria
}

\author{
Akintayo 0. Ojo ${ }^{1}$. Opeyemi O. Ogunyinka ${ }^{1} \cdot$ Oluwatoyin O. Daramola $^{1} \cdot$ Felix A. Olaoye $^{1}$
}

Received: 24 August 2020 / Accepted: 25 February 2021 / Published online: 23 March 2021

(c) The Author(s) 2021

\begin{abstract}
The use of water resources from hand-dug wells, boreholes and streams around cassava processing mills within Ilaro metropolis, Ogun State Nigeria for domestic and industrial activities had led to the assessments of water resources in the vicinities of Ekueme, Olorungbogo, Double Crown, Olalandu and Akewe cassava mills. Eleven water samples were collected and taken to the laboratories for physiochemical, heavy metals and microbial analyses. The values obtained were compared with the WHO standards for drinking water. The $\mathrm{pH}(4.68-7.41)$ revealed acidic water with relatively low temperatures $\left(24.7-29.2{ }^{\circ} \mathrm{C}\right)$. The EC $(79.80-221.00 \mathrm{mS} / \mathrm{cm})$ indicated very high level of dissolved ionic salts, TU $(0.200-0.684 \mathrm{mg} / \mathrm{L})$ revealed the presence of particulate matters, and TH $(15.10-22.70 \mathrm{mg} / \mathrm{L})$ showed moderate water hardness. The anions $\mathrm{NO}_{3}{ }^{-}$, $\mathrm{PO}_{4}{ }^{3-}$ and $\mathrm{Cl}^{-}$concentrations indicated contaminations ranging from 65.42-110.80, 7.210-8.310 and 195.25-427.00 mg/L, respectively. Cations $\mathrm{Na}^{+}, \mathrm{Ca}^{2+}$ and $\mathrm{Mg}^{2+}$ had relatively low concentrations ranging from 14.49-20.96, 4.30-11.29 and $10.50-11.50 \mathrm{mg} / \mathrm{L}$, respectively. The concentrations of $\mathrm{Fe}, \mathrm{Ni}, \mathrm{Cd}$ and $\mathrm{Pb}$ were high and ranged from 3.87-5.10, 1.27-2.82, $0.07-2.69$ and $0.03-0.96 \mathrm{mg} / \mathrm{L}$, respectively. The microbial counts in for total bacteria, fungi, E. coli and total coliform were also high ranging from 1.0-93.0, 0.1-1.3, 0.1-9.2 and 0.1-9.3 $\left(10^{6} \mathrm{CFU} / \mathrm{ml}\right)$, respectively. All these parameters indicated statistically significant difference between their concentrations at $p=0.000$ and between the physiochemical and microbial results at $p=0.006$. The qualities of the water resources around the study areas had been highly compromised and are not suitable for domestic activities.
\end{abstract}

Keywords Cassava Mills $\cdot$ Water Resources $\cdot$ Analyses $\cdot$ Hydro-chemical $\cdot$ Microbial $\cdot$ Pollution

\section{Introduction}

Groundwater quality assessment is a major aspect of groundwater studies, and the determination of physiochemical and microbial characteristics of groundwater resources is crucial for the suitability assessment of water used for different purposes such as drinking, domestic, industrial and irrigation (Andreea-Mihaela 2018; Ganiyu et al. 2018). The groundwater quality is majorly influenced by anthropogenic activities, seepage of contaminants and salt water intrusions as well as natural effects such as the geology, seasonal changes,

Akintayo O. Ojo

akintayoojo@yahoo.com

1 Department of Science Laboratory Technology, D.S. Adegbenro ICT Polytechnic, Itori-Ewekoro, Ogun State, Nigeria topography, climate and irrigation practices (Jachimowski 2017; Chaudhry et al. 2017). In order to maintain the quality of water resources, environmental protection agencies and water quality managers must on regular basis design policies and regulations that will always protect water and soil from contaminations. Studies have shown that, in most regions of the earth, most especially Africa, groundwater contaminations have become a major problem that posed serious health risks to human and also deteriorates the quality of the environment (David et al. 2014).

The appraisal of water quality is often founded on hydrochemical and microbial analyses, which provides much information about the suitability of the water resources (Onesmus 2019; Ejiogu et al. 2017; Gowrisankar et al. 2017; Palamuleni et al. 2015). Water quality generally depends on the purpose in which the water resources are used, and the maximum permissible limits for each water constituents set by regulatory bodies such as World Health 
Organisation (WHO) and Standard Organisation of Nigeria (SON) amongst others. The determination of physiochemical parameters and heavy metals concentrations plays major roles in the classification of surface water and groundwater qualities (Kayode et al. 2018). Natural water resources often consist of chemical constituents such as $\mathrm{Na}^{+}, \mathrm{Ca}^{2+}$, $\mathrm{K}^{+}, \mathrm{Mg}^{2+}, \mathrm{Cl}^{-}, \mathrm{HCO}_{3}{ }^{-}$and $\mathrm{SO}_{4}{ }^{2-}$ in moderate concentrations (Ullah et al. 2009), but the local aquifers are mostly polluted on several occasions due to some factors relating to the chemical properties or mineralogy of host rocks, as well as industrial and agricultural activities (Deshmukh 2013; Yidana et al. 2010). The water quality could be highly compromised when these factors integrate and varies over a period of time. Thus, need for continuous hydro-chemical assessments so as to always ascertain the water quality.

Heavy metals are generally present in small concentrations in water resources due to the dissolutions of natural minerals into the local aquifers. Heavy metals are generally useful in the proper functioning of human biological system, but availability in excess could lead to serious health effects (Daping et al. 2015; Wongsasuluk et al. 2014). The availability and levels of concentration of anions and cations in water determine its portability and suitability for both domestic and agricultural activities. Alkalinity or acidity of water also contributes to the quality of water for different purposes as it measures the total acid neutralising capacity of water in terms of power of hydrogen (Walton 1970). Rock matrices and soil pores filter groundwater to keep it in good quality in the aquifer, but contaminated soil will not efficiently filter the water, but rather introduce some pathogens such as bacteria, fungi and virus (Sugirtharanb et al. 2015; Anim et al. 2010). Also, water pollution due to human and animal excreta could leads to high microbial contents in the local aquifer (Gowrisankar et al. 2017; David et al. 2014). Thus, need for microbial quality assessments as a sensitive pointer to water contaminations.

Cassava processing mills generate both liquid and solid wastes that are highly harmful to human and deteriorate the quality of the environment. The solid wastes are from the cassava peels while the liquid residues are the effluents squeezed out from the grinded fermented cassava mash. The peels were usually dumped on the ground or streams, and they were allowed to rot over time thereby polluting the soil and water systems. The effluents contain biological constituents with high loads of microorganisms suitable of uncontrollably increasing the soil nutrients thereby polluting the water resources by increasing the growths of bacteria and fungi in the soil system (Onesmus 2019; Ganiyu et al. 2018). Uncontrollable industrial and domestic activities produced toxins and pathogens in water resources and a good percentage of infection and disease outbreaks could be linked to water obtained from streams, hand-dug wells and boreholes (SON 2015). In western Nigeria, cassava mills are on the increase and are usually sited around the residential areas. The sitting of boreholes and hand-dug wells very close to cassava processing mills had led to the critical assessment of water resources quality around the study areas. These water resources were majorly used for domestic activities by the inhabitants and industrial activities by the mill workers, and if the water resources are not assessed and probably treated, they could be injurious to the health of the inhabitants and mill workers. This study aimed to access the quality of water resources from hand-dug wells, boreholes and streams in the vicinity of cassava processing mills within Ilaro metropolis, Ogun State, Nigeria by carrying out both hydro-chemical and microbial analyses on the water resources.

\section{The study area}

Ilaro is on a sedimentary terrain of Southwest Nigeria (Fig. 1) underlain by limestone, clay and sands. It has a typical climate marked with significant rainfall between April and October. The dry season is short and has low impacts most especially on agricultural activities. The annual rainfall of Ilaro is $2150 \mathrm{~mm}$, and temperature is averagely $28^{\circ} \mathrm{C}$. The average humidity and dew point are $62 \%$ and $22{ }^{\circ} \mathrm{C}$, respectively. The major occupation of Ilaro people is farming, and most of the women engaged in the processing of cassava into food flakes such as Gaari and Fufu in large quantities. Five cassava processing mills that have streams, hand-dug wells and boreholes in their vicinities were considered for this study, and these mills are Ekueme, Double Crown, Olorungbogo, Olalandu and Akewe (Fig. 2).

\section{Methodology}

\section{Water samples collection and preparation for analyses}

Water samples were collected from hand-dug wells, streams and boreholes in the vicinities of cassava processing mills within Ilaro metropolis (Fig. 2). The samples were collected into half litre sterile capped container kegs which were thoroughly rinsed three times with distilled water and air dried and then rinsed again with the sample water before filled with the water samples. Residential buildings with hand-dug wells and boreholes were limited around the study areas, and a total of eleven water samples were collected to a distance of about $50 \mathrm{~m}$ away from the mills. The kegs were well cocked and numbered W1-W11 along with a proper record of sample sources and locations (Table 1). The samples were kept in coolers to regulate their temperatures, and they were immediately transported to the Chemistry and Microbiology Laboratories of the Institute of Agricultural Research and 


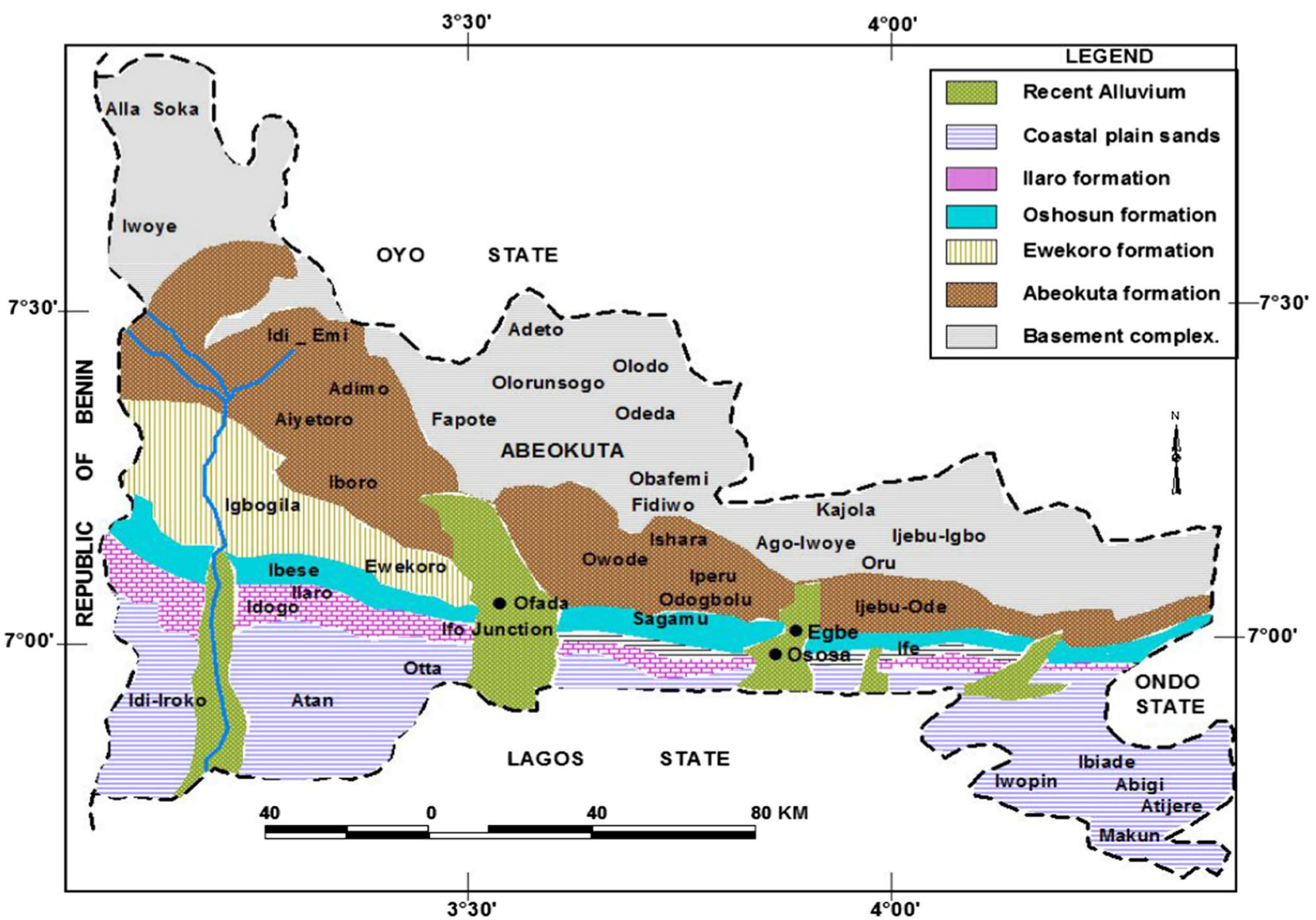

Fig. 1 Geological Map of Ogun State showing Ilaro Formation

Training, Moor Plantation, Ibadan, Nigeria for analyses in accordance with the guidelines of WHO (2017).

\section{Hydro-chemical analyses}

The parameters analysed in the water samples were power of hydrogen $(\mathrm{pH})$, Electrical Conductivity (EC), Turbidity (TU), Total Hardness (TH), Nitrite $\left(\mathrm{NO}_{3}{ }^{-}\right)$, Phosphate $\left(\mathrm{PO}_{4}{ }^{3-}\right)$, Chloride $\left(\mathrm{Cl}^{-}\right)$, Sodium $\left(\mathrm{Na}^{+}\right)$, Calcium $\left(\mathrm{Ca}^{2+}\right)$, Magnesium $\left(\mathrm{Mg}^{2+}\right)$, Iron (Fe), Nickel (Ni), Cadmium (Cd) and Lead $(\mathrm{Pb})$ according to the guidelines by WHO (2017) and SON (2015). The chemicals used were of analytical grades to prepare the reagents, and calibration standards were used for the analyses. The water temperatures were recorded on site using mercury-in-glass thermometer. The $\mathrm{pH}$ values were determined in the laboratory using a previously calibrated $\mathrm{pH}$ metre (Jenway 3510 model); the calibration was done using buffer solutions of $\mathrm{pH}$ values 4 and 7 . The EC measures the capacity of water to convey electricity or dissolved salt contents in terms of ions. It is strongly dependent on temperature and was determined using a conductivity metre (Jenway 4510 model) in milli-Siemens per centimetre $(\mathrm{mS} / \mathrm{cm})$. Turbidity in water is the measure of clarity and transparency due to the presence of organic matter and microorganism. The turbidity of the water samples was measured in Nephetometric Turbidity Unit (NTU) using the turbid metre (TB200-IR-10). Water hardness depends on the amount of magnesium or calcium salts or both in water, and it was determined by measuring about $60 \mathrm{~mL}$ of the water sample into a $250 \mathrm{~mL}$ conical flask. Then, about $3 \mathrm{~mL}$ of ammonium hydroxide buffer solution was added to the sample with about 6-8 drops of Eriochrome black-T indicator. The mixture becomes reddish and was titrated with 0.01 M disodium EDTA until a blue end solution was reached (Zieneldien 2018; Anderson et al. 2018). The titration was repeated three times to obtain a concordant titre value, and the total hardness was then determined using Eq. (1) by considering that $1 \mathrm{~mL}$ of $0.01 \mathrm{M}$ disodium EDTA equals 10 ppm total hardness of Magnesium carbonate $\left(\mathrm{MgCo}_{3}\right)$. 


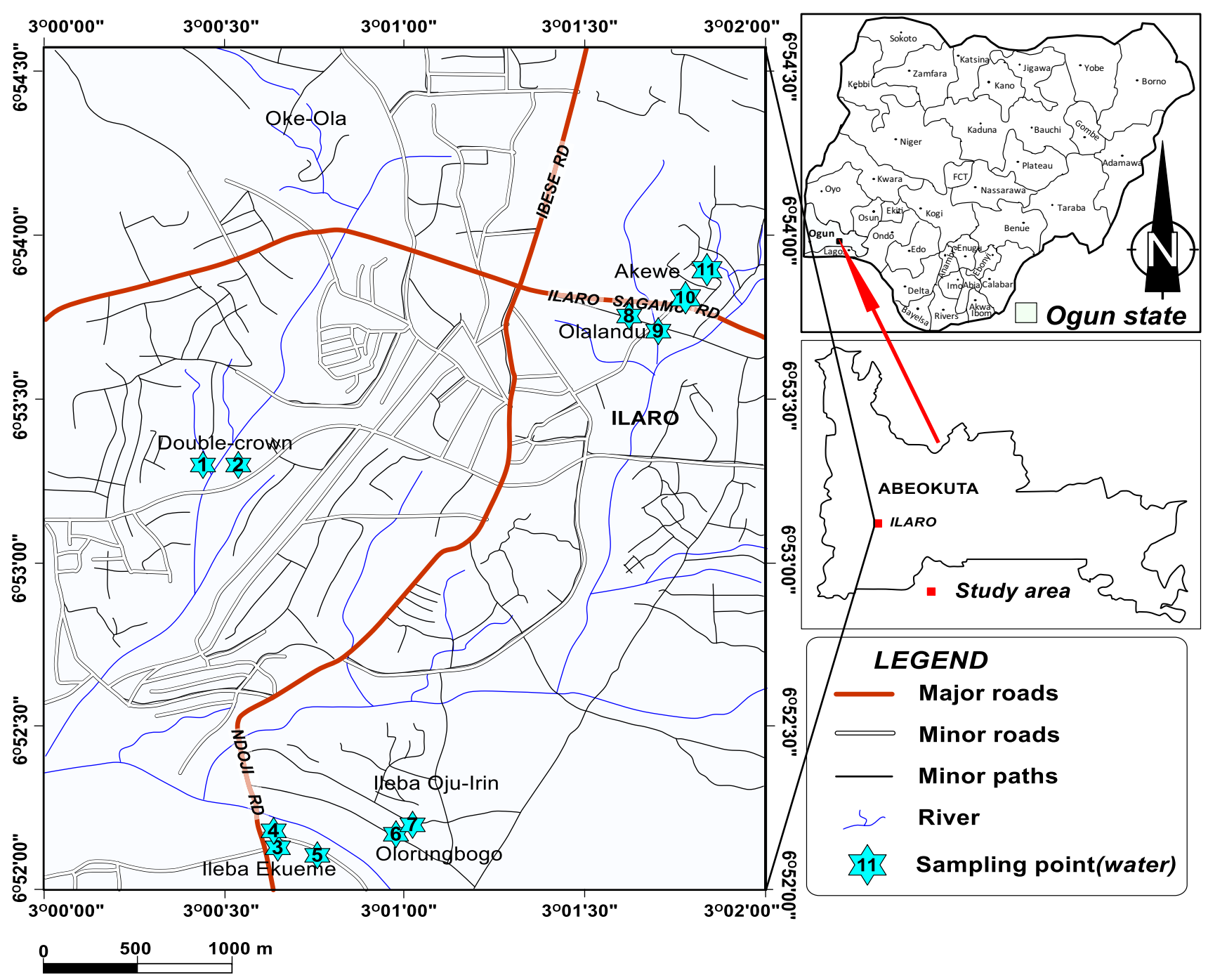

Fig. 2 The Location Map Showing the Study Areas and Sampling Points

TotalHardness $=($ TitreValue $\times 2 \times 10) p p m$

The determination of the concentrations of anions $\mathrm{NO}_{3}{ }^{-}$, $\mathrm{PO}_{4}{ }^{3-}$ and $\mathrm{Cl}^{-}$and cations $\mathrm{Na}^{+}, \mathrm{Ca}^{2+}$ and $\mathrm{Mg}^{2+}$ were carried out using spectrometric method with an ultra-violet visible spectrophotometer (Camspec model) with a $1 \mathrm{~cm}$ quartz cell (Rezaei et al. 2020; Mahadevaiah et al. 2007; Sandu et al. 2014). The heavy metals ( $\mathrm{Fe}, \mathrm{Ni}, \mathrm{Cd}, \mathrm{Pb}$ ) concentrations were determined using Flame Atomic Absorption Spectrophotometer (Ojo et al. 2020; Adejumo et al. 2018; Olagunju et al. 2018; Radulescu et al. 2014). The water samples were first digested by measuring about $100 \mathrm{~mL}$ of water samples into a $250 \mathrm{~mL}$ conical tube and adding about $20 \mathrm{~mL}$ of perchloric, nitric and sulphuric acids in the ratio 40:4:1 to the sample, and the mixture was heated until it starts to boil (Young and Tarawou 2014). The mixture was allowed to cool, and the solution was decanted, diluted and filtered. The procedure was repeated for all the samples, and the concentrations of heavy metals and ions in the solutions were determined. The validation of the measurements was done by verifying the calibration standards and instrument detection limits with the preparation and analyses of quality control samples, and the determined reproducibility measurements were less than $10 \%$ of the stated values (Ojo et al. 2020).

\section{Microbial analyses of the water samples}

The samples were analysed for Total Bacteria, Fungi, Total Coliforms and Escherichia Coliform (E. coli.) counts. The fungi and total bacteria counts were measured using pour plate techniques by pouring about $10 \mathrm{~mL}$ of the sample into $100 \mathrm{~mL}$ of distil water to give a 1:10 dilution. The serial dilutions from the suspensions were prepared to a range of $10^{6}-10^{10}$ and about $1 \mathrm{~mL}$ of the solution was aseptically plated out for total bacterial and fungal counts on Nutrient 
Table 1 Study areas, sources of water samples, codes and their coordinates

\begin{tabular}{llllll}
\hline Study Areas & Sources & Codes & Latitude $\left({ }^{\circ} \mathrm{N}\right)$ & Longitude $\left({ }^{\circ} \mathrm{E}\right)$ & Distance $(\mathrm{m})$ \\
\hline Ekueme & Hand-dug Well & W1 & $06^{\circ} 52.088^{\prime}$ & $03^{\circ} 00.710^{\prime}$ & 22 \\
Ekueme & Borehole & W2 & $06^{\circ} 52.134^{\prime}$ & $03^{\circ} 00.645^{\prime}$ & 30 \\
Ekueme & Stream & W3 & $06^{\circ} 52.201^{\prime}$ & $03^{\circ} 00.123^{\prime}$ & 10 \\
Olorungbogo & Borehole & W4 & $06^{\circ} 52.189^{\prime}$ & $03^{\circ} 01.020^{\prime}$ & 50 \\
Olorungbogo & Hand-dug Well & W5 & $06^{\circ} 52.250^{\prime}$ & $03^{\circ} 00.989^{\prime}$ & 15 \\
Double Crown & Hand-dug Well & W6 & $06^{\circ} 53.202^{\prime}$ & $03^{\circ} 00.498^{\prime}$ & 12 \\
Double Crown & Hand-dug Well & W7 & $06^{\circ} 53.232^{\prime}$ & $03^{\circ} 00^{\prime} .342$ & 25 \\
Olalandu & Hand-dug Well & W8 & $06^{\circ} 53.621^{\prime}$ & $03^{\circ} 02.009^{\prime}$ & 20 \\
Olalandu & Stream & W9 & $06^{\circ} 53.823^{\prime}$ & $03^{\circ} 01.732^{\prime}$ & 7 \\
Akewe & Hand-dug Well & W10 & $06^{\circ} 53.923$ & $03^{\circ} 02.041^{\prime}$, & 20 \\
Akewe & Stream & W11 & $06^{\circ} 53.784^{\prime}$ & $03^{\circ} 01.821^{\prime}$ & 8 \\
\hline
\end{tabular}

*Distance: Distance from the cassava mills

Table 2 The results of the physiochemical characteristics and heavy metals concentrations of the water samples

\begin{tabular}{lllllllllllll}
\hline Parameters & W1 & W2 & W3 & W4 & W5 & W6 & W7 & W8 & W9 & W10 & W11 & WHO \\
\hline $\mathrm{pH}$ & 5.73 & 7.41 & 6.09 & 6.03 & 5.69 & 5.99 & 5.97 & 5.63 & 4.68 & 5.14 & 5.22 & $6.5-8.5$ \\
$\mathrm{EC}(\mathrm{mS} / \mathrm{cm})$ & 81.8 & 89.0 & 163.4 & 82.9 & 79.8 & 218.0 & 159.4 & 217.0 & 221.0 & 169.6 & 131.6 & - \\
$\mathrm{TU}(\mathrm{NTU})$ & 0.68 & 0.66 & 0.37 & 0.40 & 0.42 & 0.21 & 0.20 & 0.20 & 0.21 & 0.20 & 0.20 & 0.2 \\
$\mathrm{TH}(\mathrm{mg} / \mathrm{L})$ & 15.10 & 15.80 & 19.50 & 15.10 & 15.10 & 22.20 & 18.30 & 22.70 & 17.50 & 18.20 & 15.10 & 100 \\
$\mathrm{NO}_{3}{ }^{-}(\mathrm{mg} / \mathrm{L})$ & 110.80 & 69.96 & 66.78 & 65.42 & 79.18 & 82.36 & 87.35 & 69.80 & 102.33 & 73.89 & 74.04 & 50 \\
$\mathrm{PO}_{4}{ }^{3-}(\mathrm{mg} / \mathrm{L})$ & 7.21 & 7.66 & 7.97 & 8.10 & 7.66 & 8.10 & 8.17 & 8.17 & 8.31 & 8.26 & 8.31 & 0.3 \\
$\mathrm{Cl}^{-}(\mathrm{mg} / \mathrm{L})$ & 195.3 & 248.5 & 230.8 & 213.0 & 427.0 & 337.3 & 266.3 & 372.8 & 372.8 & 284.0 & 230.8 & 250 \\
$\mathrm{Na}^{+}(\mathrm{mg} / \mathrm{L})$ & 20.96 & 19.48 & 16.83 & 17.43 & 17.84 & 16.06 & 16.66 & 14.49 & 14.82 & 16.24 & 15.46 & 200 \\
$\mathrm{Ca}^{2+}(\mathrm{mg} / \mathrm{L})$ & 4.30 & 4.70 & 8.00 & 4.40 & 4.50 & 10.70 & 7.50 & 11.29 & 6.00 & 6.70 & 4.60 & 200 \\
$\mathrm{Mg}{ }^{2+}(\mathrm{mg} / \mathrm{L})$ & 10.80 & 11.10 & 11.50 & 10.70 & 10.60 & 11.50 & 10.80 & 11.50 & 11.50 & 11.50 & 10.50 & 150 \\
$\mathrm{Temp} .\left({ }^{\circ} \mathrm{C}\right)$ & 29.2 & 28.7 & 25.6 & 27.9 & 28.6 & 29.0 & 28.3 & 27.8 & 24.7 & 27.4 & 25.2 & 28 \\
$\mathrm{WL}(\mathrm{m})$ & 5 & N/A & N/A & N/A & 6 & 4 & 3 & 2 & N/A & 7 & N/A & N/A \\
$\mathrm{Fe}(\mathrm{mg} / \mathrm{L})$ & 5.09 & 5.10 & 4.59 & 4.74 & 4.53 & 4.45 & 4.11 & 3.98 & 3.87 & 3.96 & 3.93 & 0.30 \\
$\mathrm{Ni}(\mathrm{mg} / \mathrm{L})$ & 2.29 & 2.80 & 2.82 & 1.99 & 2.46 & 2.32 & 1.41 & 1.52 & 1.80 & 1.47 & 1.27 & 0.07 \\
$\mathrm{Cd}(\mathrm{mg} / \mathrm{L})$ & 1.43 & 2.08 & 2.69 & 1.17 & 1.95 & 2.58 & 2.32 & 2.23 & 1.01 & 0.07 & 2.66 & 0.003 \\
$\mathrm{~Pb}(\mathrm{mg} / \mathrm{L})$ & 0.96 & 0.53 & 0.03 & 0.55 & 0.31 & 0.22 & 0.41 & 0.41 & 0.71 & 0.82 & 0.77 & 0.01 \\
\hline
\end{tabular}

WL: Water Level, N/A: Not Applicable .

Agar and Potato Dextrose Agar, respectively, and they were supplemented with about $10 \%$ lactic acid and $0.5 \%$ chloramphenicol. Then, colonies were formed, and they were counted and expressed in Colony Forming Units per millilitre $(\mathrm{CFU} / \mathrm{mL})$. The representatives of each of the purified colonies were subjected to various cultural, morphological and biochemical analyses. The identifications of the bacteria isolates were based on Bergey's manual of determinative bacteriology, and the fungi isolates were by wet mounts (Onesmus 2019; Palamuleni et al. 2015).

The total coliform bacteria counts were used to assess the cleanliness and quality of water resources. The counting procedures involves filtration of about $100 \mathrm{~mL}$ of water samples using a membrane filter, and then, the membranes were incubated on a selective media at temperature $35-37^{\circ} \mathrm{C}$ for $24 \mathrm{~h}$ (WHO 2017), and thereafter, the total coliform colonies were counted and determined using Eqs. (2).

\section{Totalcoliformcolonies}

$$
=\text { coliformcoloniescountedpersampleusedinm } L \times 100
$$

Escherichia Coli is the a type of total coliform bacteria and the most suitable indicator for faecal contaminations commonly found in the lower intestine of warm blooded animals (Gowrisankar et al. 2017). The E. coli counts revealed the bacterial indicator for human and animal faecal contaminations and in some cases tropical soils. The counting procedures involve measurement of $100 \mathrm{~mL}$ of water in a glass tube, 


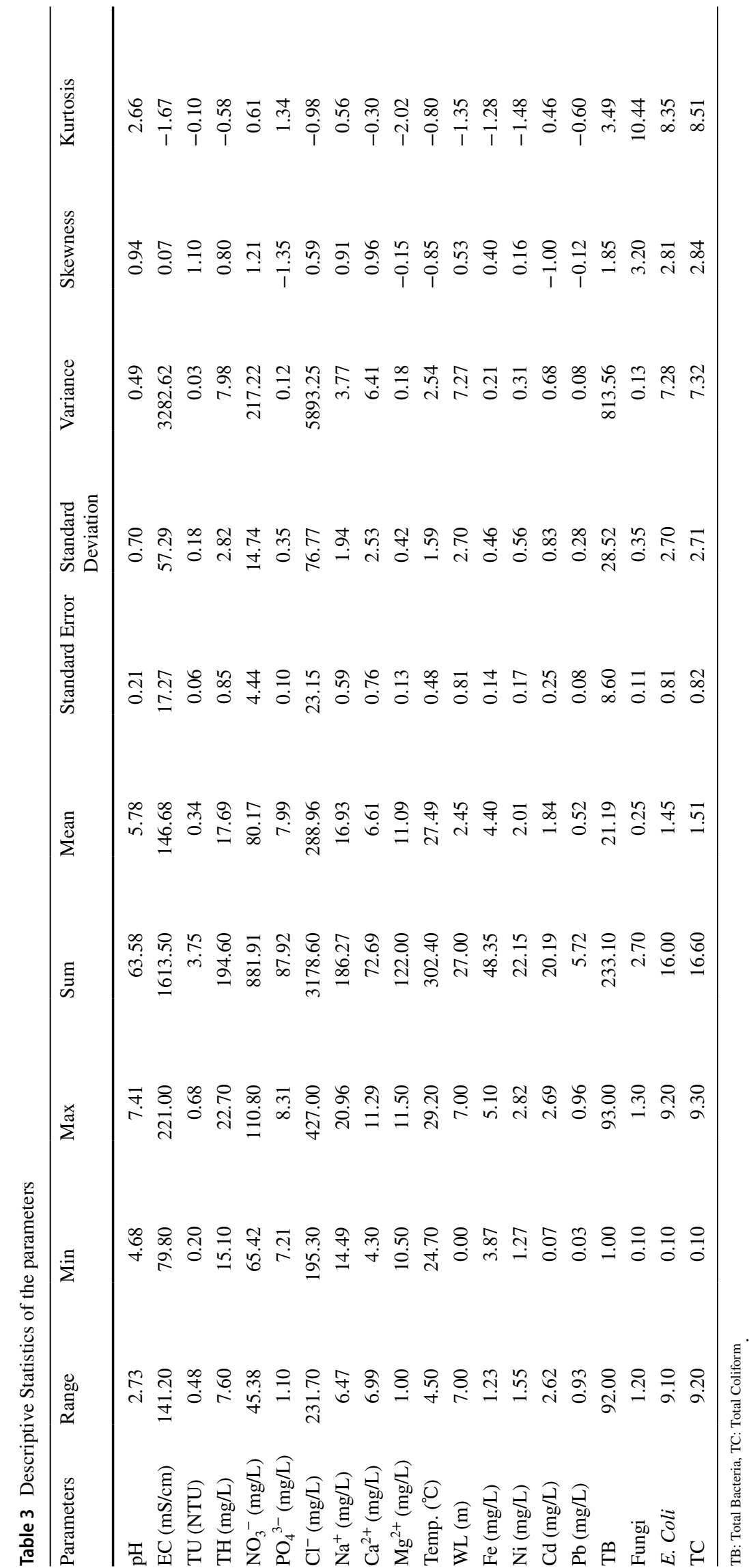




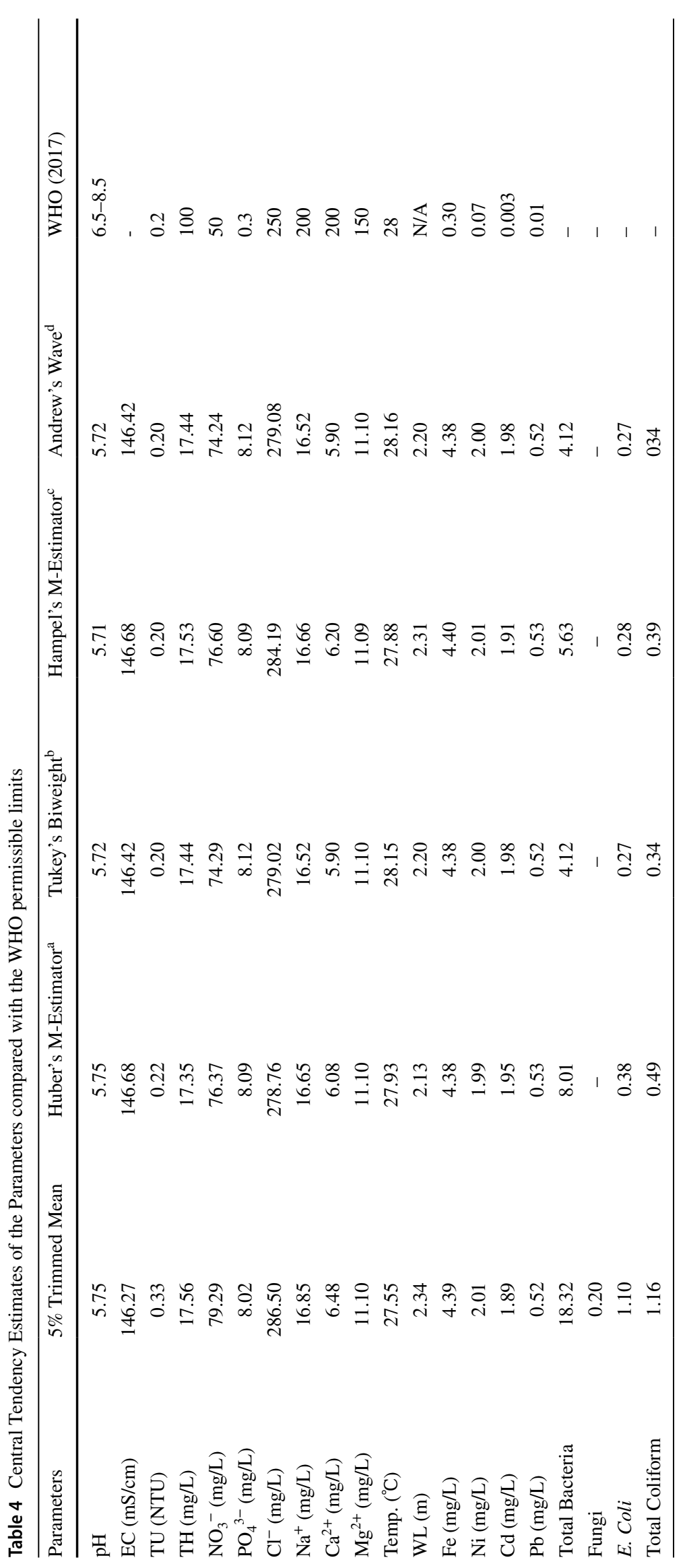




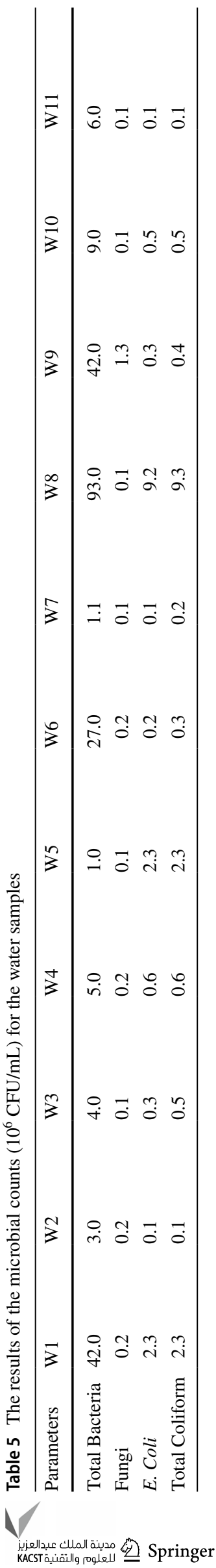

followed by membrane filtration and incubation on selective media at temperature $44-45{ }^{\circ} \mathrm{C}$ and lastly colonies counts after $24 \mathrm{~h}$ (WHO 2017).

\section{Statistical analyses}

Statistical analyses were carried out on the hydro-chemical and microbial analyses data. Descriptive statistics involving the mean, standard error, median, standard deviation, variance, kurtosis, skewness, range, minimum and maximum values and sum were derived. Also, the central tendency involving the 5\% Trimmed Mean, Huber's and Hampet's M-Estimators (Adamczyk Tomasz 2017), Tukey's Bi-weight (Kafadar 1982) and Andrew's Wave were estimated on the parameters to obtain more precise results than the analytical results obtained from the experiments because the estimates gives lower standard deviations for each of the parameters. The normality test involving Kolmogorov-Smirnow and Shapiro-Wilk was conducted to determine if the observed data are in agreement with the normal distribution since the sample size is relatively small. The Pearson's correlation matrix was carried out on the parameters to determine the extent of their relationships. Analysis of variance (ANOVA) was used to show the significant difference between the parameters that constitute contamination to the water resources and between the hydro-chemical and microbial results.

\section{Results and discussion}

\section{Physiochemical results of the water samples}

The results of the physiochemical parameters and heavy metals concentrations with their standard permissible limits by WHO (2017) are presented in Table 2. Also, the descriptive statistics and central tendency estimates of the parameters were given in Tables 3 and 4, respectively. The $\mathrm{pH}$ of the water samples ranged from 4.68-7.41, and only sample W2 was within the permissible range of 6.5-8.5. Other samples were acidic with values below 6.5 , and this could be as a result of the influence of the effluents discharging from the study areas into the subsurface. The mean $\mathrm{pH}$ value and the central tendency estimates were not within the permissible range, and this indicated that the water samples can host both toxins and microorganisms (David et al. 2014). The temperature of the water samples ranged from $24.7-29.2{ }^{\circ} \mathrm{C}$. Water with low temperature is more acceptable as they have less dissolved organic matters in them, and they also have low tendency of enhancing microorganisms' growth (WHO 2017). Samples W3, W8, W9, W10 and W11 were more suitable than the other samples as they were lower than the permissible limit of $28{ }^{\circ} \mathrm{C}$ (Kayode et al. 2018). On the average and based on the central tendency estimates, the temperatures of the water samples were close to $28{ }^{\circ} \mathrm{C}$. 
The EC generally depends on the ionic strength of the water samples, and the values obtained ranged from $79.80-221.00 \mathrm{mS} / \mathrm{cm}$. These values were extremely high with the highest and lowest values in samples W9 and W5, respectively. The mean value was $146.68 \mathrm{mS} / \mathrm{cm}$, and the standard error, standard deviation and variance were 17.27, 57.29 and $3282.62 \mathrm{mS} / \mathrm{cm}$, respectively (Table 3). The central tendency estimates had values in the same range with the mean. High EC could be as a result of effluents with increasing salt or ion contents that discharges into the subsurface from the study areas. The TU values ranged between 0.200 and $0.684 \mathrm{NTU}$, and the permissible limit is $0.20 \mathrm{NTU}$. Samples W7, W8, W10 and W11 had values on the benchmark of $0.20 \mathrm{NTU}$, while others had higher values. The highest and lowest values were 0.68 and $0.20 \mathrm{NTU}$, respectively, and the mean concentration of $0.34 \mathrm{NTU}$ was above the limit. The standard error, standard deviation and variance were 0.06 , 0.18 and $0.03 \mathrm{NTU}$, respectively. The $5 \%$ trimmed mean concentration was $0.33 \mathrm{NTU}$ and was above the limit, while other central tendency estimates were within the permissible limit except for Huber's M-Estimator with 0.22 NTU (Table 4). These results suggested that the clarity, colour and taste of the water samples had been compromised and may not be favourable for domestic activities (Anderson et al. 2018). Moreover, these water resources could harbour toxins and microbes due to the presence of particulate matters (SON 2015), and this corroborated with the earlier studies of Afuye et al. (2015). The total hardness of the water samples ranged from $15.10-22.70 \mathrm{mg} / \mathrm{L}$, and they were all below the permissible limit of $100 \mathrm{mg} / \mathrm{L}$. The mean and other central tendency estimates indicated low contents of magnesium or and calcium salts.

The concentrations of $\mathrm{NO}_{3}{ }^{-}$varied from $65.42-110.80 \mathrm{mg} / \mathrm{L}$, and all the samples indicated values above the permissible concentration of $50 \mathrm{mg} / \mathrm{L}$. The mean concentration was $80.17 \mathrm{mg} / \mathrm{L}$ with $4.44 \mathrm{mg} / \mathrm{L}$ standard error, $14.74 \mathrm{mg} / \mathrm{L}$ standard deviation and $217.22 \mathrm{mg} / \mathrm{L}$ variance. The central tendency estimations also indicated increased of nitrites in the water samples. The lowest and highest concentrations of 65.42 and $110.80 \mathrm{mg} / \mathrm{L}$ were observed in samples W4 and W1, respectively. These results revealed $\mathrm{NO}_{3}{ }^{-}$pollution, and this could be as a result of seepage of wastewater and organic wastes from the study areas into the subsurface (Sugirtharan 2015). Nitrite is highly soluble, and its excess in water could be harmful to man (WHO 2017). The concentrations of $\mathrm{PO}_{4}{ }^{3-}$ ranged from $7.21-8.31 \mathrm{mg} / \mathrm{L}$, and these values were higher than the permissible limit of $0.3 \mathrm{mg} / \mathrm{L}$. The mean concentration of $\mathrm{PO}_{4}{ }^{3-}$ was $7.99 \mathrm{mg} / \mathrm{L}$ with $0.10 \mathrm{mg} / \mathrm{L}$ standard error, $0.35 \mathrm{mg} / \mathrm{L}$ standard deviation and $0.12 \mathrm{mg} / \mathrm{L}$ variance. Also, the central tendency estimates indicated high concentrations of $\mathrm{PO}_{4}{ }^{3-}$. Phosphates affect water quality by enhancing the excessive growth of Algae which limits the flow of oxygen in the water system thereby increasing the level of water toxins (WHO 2017; Adelekan 2010). The concentrations of $\mathrm{Cl}^{-}$in the water samples ranged from $195.3-427.0 \mathrm{mg} / \mathrm{L}$, and samples W1, W2, W3, W4 and W11 showed concentrations below the permissible limit of $250 \mathrm{mg} / \mathrm{L}$, while others revealed higher concentrations. The mean concentration of $288.96 \mathrm{mg} / \mathrm{L}$ was above the permissible limit, and the standard error, standard deviation and variance were 23.15 , 76.77 and $5893.25 \mathrm{mg} / \mathrm{L}$. The central tendency estimates also indicated concentrations higher than the permissible limits. Occasional applications of Chlorine to hand-dug wells and boreholes could have contributed to the increase of $\mathrm{Cl}^{-}$in the samples apart from the possible seepage of effluents from the mills. Chloride corrodes pipes and fittings which could deposit toxic metals in water over time. In general, anion concentrations were high in the water samples, and these could be from the effluents seeping from cassava mills (Sugirtharan 2015).

The concentrations of $\mathrm{Na}^{+}$ranged from $14.49-20.96 \mathrm{mg} / \mathrm{L}$, and they were all below the permissible limit of $200 \mathrm{mg} / \mathrm{L}$. The mean concentration of $\mathrm{Na}^{+}$ was $16.93 \mathrm{mg} / \mathrm{L}$ with $0.59 \mathrm{mg} / \mathrm{L}$ standard error, $1.94 \mathrm{mg} / \mathrm{L}$ standard deviation and $3.77 \mathrm{mg} / \mathrm{L}$ variance. Sodium concentrations in portable water are usually around $20 \mathrm{mg} / \mathrm{L}$ (WHO 2017; EPA 2003), and this concentration could be higher overtime by adding water softeners or contaminants seepage from industrial and domestic activities. Calcium ion causes hardness in groundwater, and the calcium contents in the water samples were found between 4.30 and $11.29 \mathrm{mg} / \mathrm{L}$, and these samples revealed very low concentrations of $\mathrm{Ca}^{2+}$ below the permissible limit of $200 \mathrm{mg} / \mathrm{L}$. The mean concentration was $6.61 \mathrm{mg} / \mathrm{L}$ with standard error of $0.76 \mathrm{mg} / \mathrm{L}$, standard deviation of $2.53 \mathrm{mg} / \mathrm{L}$ and variance of $6.41 \mathrm{mg} / \mathrm{L}$. The $\mathrm{Mg}^{2+}$ concentrations ranged from $10.50-11.50 \mathrm{mg} / \mathrm{L}$, and the water samples had concentrations lower than the permissible limit of $150 \mathrm{mg} / \mathrm{L}$. The mean concentration was $11.09 \mathrm{mg} / \mathrm{L}$ with $0.13 \mathrm{mg} / \mathrm{L}$ standard error, $0.42 \mathrm{mg} / \mathrm{L}$ standard deviation and $0.18 \mathrm{mg} / \mathrm{L}$ variance. The low concentrations of $\mathrm{Ca}^{2+}$ and $\mathrm{Mg}^{2+}$ indicated that the hardness of the water samples was moderate and within the permissible range. In general, the results revealed low concentrations of the cations, and also the central tendency estimates were very low, and all these suggested that the cations had bearable and permissible concentrations in the water samples.

\section{Results of heavy metals concentrations in the water samples}

The concentrations of $\mathrm{Fe}, \mathrm{Ni}, \mathrm{Cd}$ as well as $\mathrm{Pb}$ in the analysed samples were presented in Table 2 . The concentrations of Fe ranged from $3.87-5.10 \mathrm{mg} / \mathrm{L}$, and these values

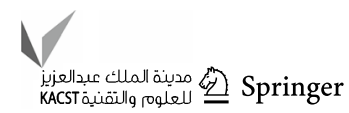


Table 6 Normality test of the parameters

\begin{tabular}{|c|c|c|c|c|c|c|}
\hline \multirow[t]{2}{*}{ Parameters } & \multicolumn{3}{|c|}{ Kolmogorov-Smirnov $^{a}$} & \multicolumn{3}{|c|}{ Shapiro-Wilk } \\
\hline & Statistic & Df & Sig & Statistic & Df & Sig \\
\hline $\mathrm{pH}$ & 0.237 & 11 & 0.840 & 0.905 & 11 & 0.214 \\
\hline $\mathrm{EC}(\mathrm{mS} / \mathrm{cm})$ & 0.207 & 11 & 0.200 & 0.863 & 11 & 0.063 \\
\hline TU (NTU) & 0.306 & 11 & 0.005 & 0.765 & 11 & 0.003 \\
\hline $\mathrm{TH}(\mathrm{mg} / \mathrm{L})$ & 0.203 & 11 & 0.200 & 0.849 & 11 & 0.041 \\
\hline $\mathrm{NO}_{3}{ }^{-}(\mathrm{mg} / \mathrm{L})$ & 0.207 & 11 & 0.200 & 0.864 & 11 & 0.064 \\
\hline $\mathrm{PO}_{4}{ }^{3-}(\mathrm{mg} / \mathrm{L})$ & 0.258 & 11 & 0.039 & 0.839 & 11 & 0.031 \\
\hline $\mathrm{Cl}^{-}(\mathrm{mg} / \mathrm{L})$ & 0.162 & 11 & 0.200 & 0.918 & 11 & 0.300 \\
\hline $\mathrm{Na}^{+}(\mathrm{mg} / \mathrm{L})$ & 0.158 & 11 & 0.200 & 0.937 & 11 & 0.485 \\
\hline $\mathrm{Ca}^{2+}(\mathrm{mg} / \mathrm{L})$ & 0.229 & 11 & 0.111 & 0.843 & 11 & 0.034 \\
\hline $\mathrm{Mg}^{2+}(\mathrm{mg} / \mathrm{L})$ & 0.291 & 11 & 0.010 & 0.807 & 11 & 0.012 \\
\hline Temp. $\left({ }^{\circ} \mathrm{C}\right)$ & 0.213 & 11 & 0.174 & 0.864 & 11 & 0.065 \\
\hline WL (m) & 0.273 & 11 & 0.021 & 0.841 & 11 & 0.033 \\
\hline $\mathrm{Fe}(\mathrm{mg} / \mathrm{L})$ & 0.188 & 11 & 0.200 & 0.892 & 11 & 0.148 \\
\hline $\mathrm{Ni}(\mathrm{mg} / \mathrm{L})$ & 0.174 & 11 & 0.200 & 0.922 & 11 & 0.333 \\
\hline $\mathrm{Cd}(\mathrm{mg} / \mathrm{L})$ & 0.191 & 11 & 0.200 & 0.900 & 11 & 0.185 \\
\hline $\mathrm{Pb}(\mathrm{mg} / \mathrm{L})$ & 0.115 & 11 & 0.200 & 0.983 & 11 & 0.980 \\
\hline Total Bacteria & 0.302 & 11 & 0.006 & 0.738 & 11 & 0.001 \\
\hline Fungi & 0.460 & 11 & 0.000 & 0.450 & 11 & 0.000 \\
\hline E. Coli & 0.352 & 11 & 0.000 & 0.562 & 11 & 0.000 \\
\hline Total Coliform & 0.359 & 11 & 0.000 & 0.561 & 11 & 0.000 \\
\hline
\end{tabular}

were far above the permissible limit of $0.30 \mathrm{mg} / \mathrm{L}$. The mean concentration of Fe was $4.40 \mathrm{mg} / \mathrm{L}$ with $0.14 \mathrm{mg} / \mathrm{L}$ standard error, $0.46 \mathrm{mg} / \mathrm{L}$ standard deviation and $0.21 \mathrm{mg} / \mathrm{L}$ variance. The water samples indicated Fe pollutions and the sources of Fe in water are through natural activities such as rock weathering, seepage of industrial effluents, acid-mine drainage as well as sewage and landfill contaminants migrations (WHO 2017; Ruqia et al. 2015). The concentrations of $\mathrm{Ni}$ ranged from 1.27-2.82 mg/L, and these values were all above the permissible limits of $0.07 \mathrm{mg} / \mathrm{L}$. The mean concentration of $\mathrm{Ni}$ was $2.01 \mathrm{mg} / \mathrm{L}$ with standard error of $0.17 \mathrm{mg} / \mathrm{L}$, standard deviation of $0.56 \mathrm{mg} / \mathrm{L}$ and variance of $0.31 \mathrm{mg} / \mathrm{L}$. These values indicated high pollution of $\mathrm{Ni}$, which could cause serious health injuries if the water is used for domestic and agricultural activities (Ejiogu et al. 2017). The concentrations of Cd ranged from $0.07-2.69 \mathrm{mg} / \mathrm{L}$, and these values were all above the permissible limit of $0.003 \mathrm{mg} / \mathrm{L}$. The mean concentration of $1.84 \mathrm{mg} / \mathrm{L}$, standard error of $0.25 \mathrm{mg} / \mathrm{L}$, standard deviation of $0.83 \mathrm{mg} / \mathrm{L}$ and variance of $0.68 \mathrm{mg} / \mathrm{L}$ revealed that the water samples were polluted with cadmium which could be due to the infiltrations of effluents into the subsurface from the study areas. The concentrations of $\mathrm{Pb}$ ranged from $0.03-0.96 \mathrm{mg} / \mathrm{L}$, and these values were higher than the permissible limit of $0.010 \mathrm{mg} / \mathrm{L}$. The water samples were highly polluted with lead having mean concentration value of $0.52 \mathrm{mg} / \mathrm{L}$ with $0.08 \mathrm{mg} / \mathrm{L}$ standard error, $0.28 \mathrm{mg} / \mathrm{L}$ standard deviation and $0.08 \mathrm{mg} / \mathrm{L}$ variance. Cadmium and Lead are major sources of water pollution and in most cases they migrate into the water systems through the effluents discharging from industrial activities as well as leachates from landfills (Ojo et al. 2020; Ruqia et al. 2015; Adelekan 2010). The central tendency estimates indicated heavy metals pollutions as their values were not within the permissible limits.

\section{Microbial analysis of the water samples}

The results for the microbial counts such as Total Bacteria (TB), Fungi, Escherichia Coli and Total Coliform (TC) expressed in $10^{6} \mathrm{CFU} / \mathrm{mL}$ were presented in Table 5. The permissible level for microbe in water is 0 per $100 \mathrm{~mL}$ (WHO 2017; SON 2015), and this implies that good and potable water resources are expected to be totally free of microbes.

The total bacteria counts in the samples ranged from 1.0-93.0 $\left(10^{6} \mathrm{CFU} / \mathrm{mL}\right)$. The highest and lowest bacteria counts were observed in W8 and W5, respectively. The mean count, standard error, standard deviation and variance were $21.19,8.60,28.52$ and $813.56\left(10^{6} \mathrm{CFU} / \mathrm{mL}\right)$, respectively, and these values revealed high bacteria counts. High counts of $42\left(10^{6} \mathrm{CFU} / \mathrm{mL}\right)$ were recorded in samples $\mathrm{W} 1$ and $\mathrm{W} 9$, a count of $27.0\left(10^{6} \mathrm{CFU} / \mathrm{mL}\right)$ was recorded in sample W6, while other samples indicated total bacteria counts ranging from 1.0-9.0 (10 6 CFU/mL). In general, samples W1, W6, W8 and W9 revealed very high total bacteria counts while 


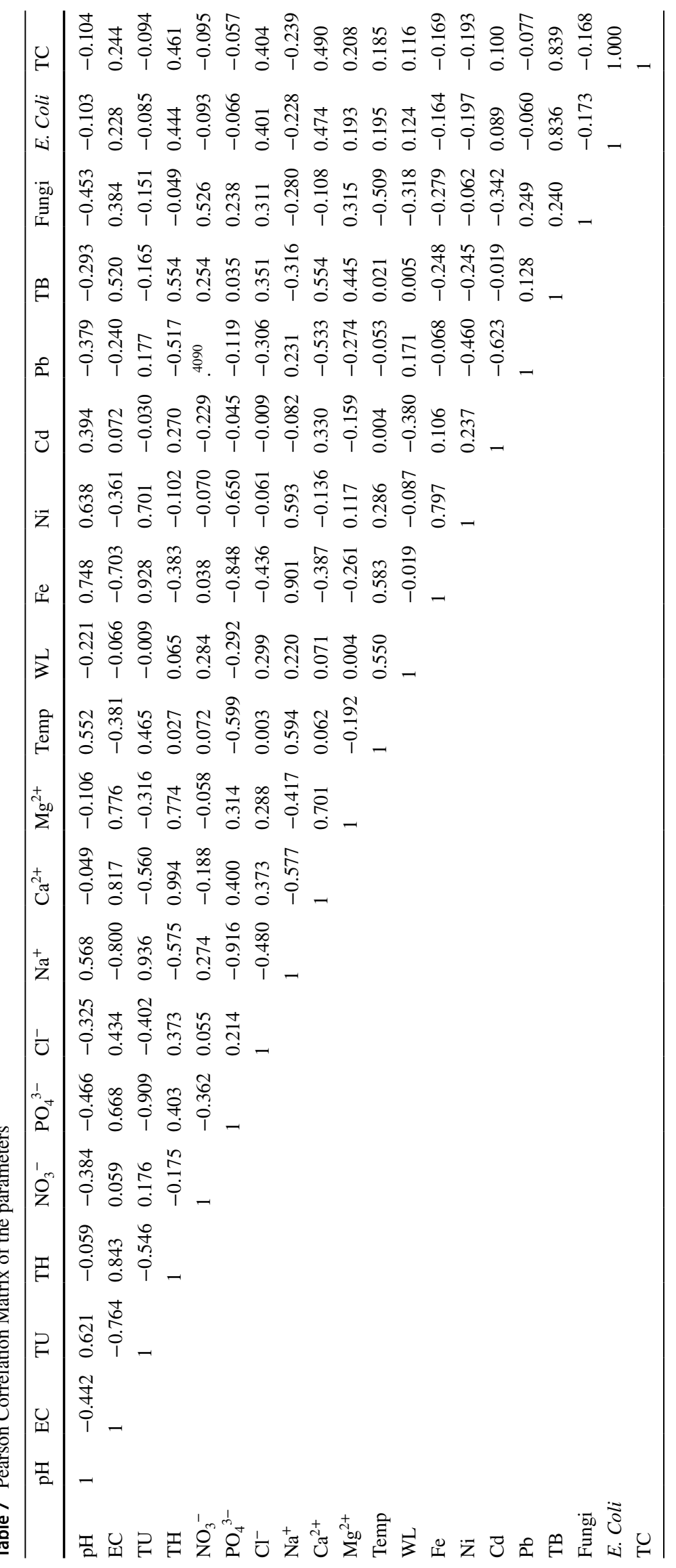


Table 8 Analysis of Variance

\begin{tabular}{lrlrll}
\hline & Sum of Squares & Df & Mean Square & F & Sig \\
\hline Sample & $1,019,970.177$ & 19 & $53,682.641$ & 104.732 & 0.000 \\
Error & $102,514.515$ & 200 & 512.573 & & \\
Total & $1,122,484.692$ & 219 & & & \\
\hline
\end{tabular}

Table 9 Comparison between the Physiochemical and Microbial Results

\begin{tabular}{lrlrll}
\hline & Sum of Squares & Df & Mean Square & F & Sig \\
\hline Between Results & $37,662.948$ & 1 & $37,662.948$ & 7.569 & 0.006 \\
Within Results & $1,084,821.744$ & 218 & 4976.247 & & \\
Total & $1,122,484.692$ & 219 & & & \\
\hline
\end{tabular}

samples W2, W3, W4, W5, W7, W10 and W11 revealed fairly high counts. According to Bhattarai et al. (2015), high bacteria counts in water resources are as a result of the high presence of bacteria in soils between $10^{8}-10^{9}$ cells per gram and the versatility of bacteria metabolism in water. In lieu of the above, high bacteria counts in the samples could be due to high concentrations of cassava effluents infiltrating into the subsurface through the soil pores to contaminate the water resources. Recent studies had shown that groundwater cannot be totally free of bacteria, but could be avoided to the level that the pathogens won't have any significant effects on human (Ejiogu et al. 2017; Sugirtharan 2015; David et al. 2014).

Fungi counts ranged between 0.1 and $1.3\left(10^{6} \mathrm{CFU} / \mathrm{mL}\right)$ and the lowest count of $0.1\left(10^{6} \mathrm{CFU} / \mathrm{mL}\right)$ were recorded in samples W3, W5, W7, W8, W10 and W11. Also, samples with fungi count of $0.2\left(10^{6} \mathrm{CFU} / \mathrm{mL}\right)$ were $\mathrm{W} 1, \mathrm{~W} 2, \mathrm{~W} 4$ and $\mathrm{W} 6$, while the highest count of $1.3\left(10^{6} \mathrm{CFU} / \mathrm{mL}\right)$ was recorded in W9. The mean count of 0.25 , standard error of 0.11 , standard deviation of 0.35 and variance of 0.13 (all expressed in $10^{6} \mathrm{CFU} / \mathrm{mL}$ ) indicated high fungi pollution in all the water samples, and this may be due to the effluent discharging from the cassava mills into the subsurface. The presence of fungi in water is generally considered as contaminants because it affects the taste and gives odour to the water by destroying the nutrients in the water and deposit toxins such as allergens and pathogens (WHO 2017). The total coliform and E. Coli counts were within the same range of $0.1-9.3$ and $0.1-9.2\left(10^{6} \mathrm{CFU} / \mathrm{mL}\right)$, respectively. The mean $E$. Coli count was 1.45 with 0.81 standard error, 2.70 standard deviation and 7.28 variance (all expressed in $10^{6} \mathrm{CFU} / \mathrm{mL}$ ). The mean total coliform count was 1.51 , standard error of 0.82 , standard deviation of 2.71 and variance of 7.32 (all expressed in $10^{6} \mathrm{CFU} / \mathrm{mL}$ ). These microorganisms grow and survive in both natural and sewage waters, and they can be contacted by man through the materials in the environment and faecal contaminations (Ejiogu et al. 2017). The lowest counts of $0.1\left(10^{6} \mathrm{CFU} / \mathrm{mL}\right)$ for $E$. coli were observed in samples W2, W7 and W11 and that of the total coliform in samples W2 and W11. The high total coliform and E. coli counts of $2.3\left(10^{6} \mathrm{CFU} / \mathrm{mL}\right)$ were in samples W1 and W5, and also their highest counts of 9.2 and $9.3\left(10^{6} \mathrm{CFU} / \mathrm{mL}\right)$, respectively, were recorded in sample W8. Other samples revealed low counts of less than 1 $\left(10^{6} \mathrm{CFU} / \mathrm{mL}\right)$ for both total coliform and $E$. coli counts. The central tendency estimates for microbial counts as shown in Table 4 indicated microbial pollutions which could have been influenced by the effluents seeping into the subsurface from the study areas.

\section{Normality test}

Kolmogorov-Smirnov and Shapiro-Wilk tests (Table 6) were adopted to detect all departures from normality. For all the significant values that are greater than 0.05 , the parameters were within the normal distribution, but for values below 0.05 , this indicated that the parameter has significantly deviate from the normal distribution. The Kolmogorov-Smirnov tests indicate that parameters $\mathrm{TU}, \mathrm{PO}_{4}{ }^{3-}, \mathrm{Mg}^{2+}$ and all the microbial counts does not follow the normal distributions, while other parameters follow normal distributions in the entire population. Also, in the Shapiro-Wilk tests, parameters TU, TH, $\mathrm{PO}_{4}{ }^{3-}, \mathrm{Ca}^{2+}, \mathrm{Mg}^{2+}$ and all the microbial counts significantly deviate from the normal distributions, while other parameters does not deviate from the normality.

\section{Pearson correlation matrix}

The correlation analysis for both physiochemical and microbial parameters are shown in Table 7. EC had negative moderate correlation with $\mathrm{pH}$ and $\mathrm{TU}$ had high degree of correlation with $\mathrm{pH}$. TH had strong correlation with EC and strong negative correlation with $\mathrm{pH}$ and $\mathrm{TU}$. The temperature of the water samples was moderately correlated with $\mathrm{pH}, \mathrm{TU}$ and $\mathrm{Na}^{+}$and had very low correlation with $\mathrm{TH}$, $\mathrm{NO}_{3}{ }^{-}, \mathrm{Cl}^{-}$and $\mathrm{Ca}^{2+}$. For the cations, $\mathrm{NO}_{3}{ }^{-}$had low degree of correlation with EC and TU and low negative correlation with $\mathrm{pH}$ and $\mathrm{TH} . \mathrm{PO}_{4}{ }^{3-}$ had strong correlation with $\mathrm{EC}$ and medium correlation with $\mathrm{TH} . \mathrm{Cl}^{-}$had moderate correlation with $\mathrm{EC}$ and $\mathrm{TH}$ and low correlation with $\mathrm{PO}_{4}{ }^{3-}$ and $\mathrm{NO}_{3}{ }^{-}$. Also, for the anions, $\mathrm{Na}^{+}$had high correlation with $\mathrm{pH}$ and $\mathrm{TU}$, and negative high correlation with $\mathrm{EC}, \mathrm{TH}$ and $\mathrm{PO}_{4}{ }^{3-}$. $\mathrm{Ca}^{2+}$ was perfectly correlated with $\mathrm{TH}$ as that calcium is the major constitute of the low water hardness. Also, $\mathrm{Ca}^{2+}$ had strongly correlation with $\mathrm{EC}$ and moderate correlation with $\mathrm{PO}_{4}{ }^{3-}$ and $\mathrm{Cl}^{-} . \mathrm{Mg}^{2+}$ was highly correlated to $\mathrm{EC}, \mathrm{TH}$ and $\mathrm{Ca}^{2+}$; this is understandable as $\mathrm{Mg}^{2+}$, and $\mathrm{Ca}^{2+}$ contributes 
to water hardness and conductivity. $\mathrm{Mg}^{2+}$ also had moderate correlation with $\mathrm{PO}_{4}{ }^{3-}$ and low correlation with $\mathrm{Cl}^{-}$.

For the heavy metals, Fe had very strong correlations with $\mathrm{pH}, \mathrm{TU}$, temperature and $\mathrm{Na}^{+}$and low correlation with $\mathrm{NO}_{3}{ }^{-}$. Ni was highly correlated with $\mathrm{pH}, \mathrm{TU}, \mathrm{Na}^{+}$and $\mathrm{Fe}$ and also had low correlation with temperature and $\mathrm{Mg}^{2+}$. $\mathrm{Cd}$ was moderately correlated with $\mathrm{pH}$ and $\mathrm{Ca}^{2+}$ and had low correlation with EC, $\mathrm{TH}, \mathrm{Fe}, \mathrm{Ni}$ and temperature. Lead had low correlation with $\mathrm{TH}$ and $\mathrm{Na}^{+}$and moderate correlation with $\mathrm{NO}_{3}{ }^{-} . \mathrm{Pb}$ had strong negative correlation with $\mathrm{TH}$, $\mathrm{Ca}^{2+}$ and $\mathrm{Cd}$, negative moderate correlation with $\mathrm{pH}, \mathrm{NO}_{3}{ }^{-}$, $\mathrm{Cl}^{-}$and $\mathrm{Ni}$ and negative low correlation with $\mathrm{EC}, \mathrm{PO}_{4}{ }^{3-}$, $\mathrm{Mg}^{2+}, \mathrm{Fe}$ and temperature. This implies that, as the concentrations of lead increases, the concentration of all these parameters decreased.

The microbial counts were correlated with the physiochemical analytical data. The total bacteria were highly correlated with EC, $\mathrm{TH}$ and $\mathrm{Ca}^{2+}$, moderately correlated with $\mathrm{Cl}^{-}$and $\mathrm{Mg}^{2+}$ and also had low correlation with $\mathrm{NO}_{3}{ }^{-}$, $\mathrm{PO}_{4}{ }^{3-}$ and $\mathrm{Pb}$. Fungi were in high correlation with $\mathrm{NO}_{3}{ }^{-}$, moderate correlation with $\mathrm{EC}, \mathrm{Cl}^{-}$and $\mathrm{Mg}^{2+}$ and low correlation with $\mathrm{NO}_{3}{ }^{-}, \mathrm{Pb}$ and total bacteria counts. E. Coli. were in high correlation with total bacteria, moderate correlation with $\mathrm{TH}, \mathrm{Cl}^{-}$and $\mathrm{Ca}^{2+}$ and low correlation with $\mathrm{EC}, \mathrm{Mg}^{2+}$, $\mathrm{Cd}$ and temperature. The total coliform were in perfect correlation with $E$. Coli. and this indicated that whatever influence the total coliform counts contributes to the counts of E. Coli. Also, total coliform was highly correlated with TH, $\mathrm{Cl}^{-}, \mathrm{Ca}^{2+}$ and total bacteria.

*TB: Total Bacteria, TC: Total Coliform.

\section{Analysis of variance}

Tables 8 and 9 presented the outputs of the ANOVA analyses and revealed a statistically significant difference in the results. Table 8 showed a significance value of 0.000 , that is, $p=0.000$, and this indicated statistical significant difference between the concentrations, values or counts of the parameters under investigation. In Table 9, the significance value is $0.006(p=0.006)$, which is below 0.05 , and therefore indicated a statistically significant difference between the physiochemical and microbial results.

\section{Treatments and regulations to improve the water quality}

The process of treating water is majorly based on the types of water and the degrees of contamination (Wołowiec et al., 2019). The water analyses indicated low $\mathrm{pH}$ values and high electrical conductivities, turbidities, concentrations of anions $\left(\mathrm{NO}_{3}{ }^{-}, \mathrm{PO}_{4}{ }^{3-}\right.$ and $\left.\mathrm{Cl}^{-}\right)$and heavy metals $(\mathrm{Fe}, \mathrm{Ni}, \mathrm{Cd}$ and $\mathrm{Pb})$, as well as microbial populations. Due to the aforementioned, it is expected that more than one of the standard processes of water treatment should be applied for the water treatment. Injection of sodium carbonate and sodium hydroxide into the water system increases the $\mathrm{pH}$ of the water to near neutral (Wagenet et al., 1995). The turbidity of the water could be reduced through chemical coagulation which involves the addition of alum or aluminium sulphate or polymer to the water. The particles in the water coagulate and form larger particles that can easily be removed through sedimentation or filtration. Sedimentation involves the particles in the water to settle out of the liquid, mostly at the bottom of the container. Filtration involves the water passing through filters; majorly composed of gravel and sand or in many cases crushed anthracite. These processes of sedimentation and filtration remove all impurities such as inorganic and particulate matters. The disinfection gets rid of diseasecausing microbes such as parasites, bacteria and viruses. Chlorine is very effective in disinfection, and filtration also helps in disinfecting the water. The water samples could also be subjected to ultrafiltration and ultra-violent sterilisation In recent time, several techniques have been adopted to remove anions and heavy metals from polluted water (Wołowiec et al., 2019), but absorption technique has been regarded to be the most efficient, cost effective and ease of operation (Davarnejad et al. 2016; Cochrane et al. 2006).

Water contamination regulation has been a top environmental policy priority for years, but yet significant water quality problems remain. These problems are enormous due to the lack of provision of quality water system by the regulators and policy makers in Nigeria. Individual citizens provide water by sinking boreholes and digging handdug well on any available place within their vicinities not minding any potential contaminants or threats to the water system, such as both solid and liquid wastes. There is high tendency of increase in the degree of water pollution around the study areas as the cassava mills age. As such and in order to improve the water quality, the cassava processing mills should be relocated to a site at reasonably distances to the residential areas.

\section{Conclusion}

Human rely mostly on water resources for drinking as well as for domestic, industrial and other socio-economic activities. Therefore, it is necessary to constantly assess water quality for its suitability for human use and also where necessary to safeguard it from contaminants that could make it pose injurious health risks on man. Hydro-chemical and microbial techniques had been adopted to analysed the quality of water samples obtained around the study areas. The 
samples were acidic and had low temperatures and TU values, as well as high EC and TH values, which suggested that the water quality had been compromised and had high tendencies of accommodating toxins and microorganisms. The concentrations of anions and heavy metals were also high. The total bacteria, fungi, E. coli and total coliform counts in the water samples revealed high microbial contaminations which could lead to diverse gastro-intestinal disorders. The streams, hand-dug wells and boreholes within the vicinity of the cassava mills to a distance of about $50 \mathrm{~m}$ away are not suitable for drinking and any other domestic activities without appropriate and adequate water treatments.

Financial disclosure statement The author(s) received no specific funding for this work.

\section{Declarations}

Conflict of interest Not applicable.

Open Access This article is licensed under a Creative Commons Attribution 4.0 International License, which permits use, sharing, adaptation, distribution and reproduction in any medium or format, as long as you give appropriate credit to the original author(s) and the source, provide a link to the Creative Commons licence, and indicate if changes were made. The images or other third party material in this article are included in the article's Creative Commons licence, unless indicated otherwise in a credit line to the material. If material is not included in the article's Creative Commons licence and your intended use is not permitted by statutory regulation or exceeds the permitted use, you will need to obtain permission directly from the copyright holder. To view a copy of this licence, visit http://creativecommons.org/licenses/by/4.0/.

\section{References}

Adejumo RO, Adagunodo TA, Bility H, Lukman AF, Isibor PO (2018) Physicochemical Constituents of Groundwater and its Quality in Crystalline Bedrock, Nigeria. International Journal of Civil Engineering and Technology 9(8):887-903

Adelekan BA (2010) Water Quality of Domestic wells in typical African Communities: A case study from Nigeria. International Journal of Water Resources and Environmental Engineering 2(6):137-147

Afuye GG, Mogaji KO (2015) Effect of Cassava Effluents on Domestic Consumption of Shallow Well water in Owo Local Government Area, Ondo State. Nigeria Physical Science Research International $3(3): 37-43$

Anderson L, Figueroa J, Lykourinon V (2018) General Chemistry II Laboratory Manual, pp. 10-73, Tampa, Florida, USA: University of South Florida-Department of Chemistry.

Andreea-Mihaela Dunca (2018) Water Pollution and Water Quality Assessment of Major Transboundary Rivers from Banat (Romania). Journal of Chemistry Article. 9073763: 8. http://dx.doi. org/https://doi.org/10.1155/2018/9073763.

Anim F, Nyame FK, Armah TK (2010) Coliform status of water bodies from two districts in Ghana, West Africa: implications for rural water resources management. Water Policy Journal 20:734-745

Bhattarai A, Bhattarai B, Pandey S (2015) Variation of Soil Microbial Population in Different Soil Horizons. Journal of Microbiology and Experimentation. 2(2); 75-78. http://dx.doi.org/https://doi. org/10.15406/jmen.2015.02.00044.

Chaudhry FN, Malik MF (2017) Factors Affecting Water Pollution: A Review. Journal of Ecosystem and Ecography 7:225. https:// doi.org/10.4172/2157-7625.1000225

Cochrane E, Lu S, Gibb S, Villaescusa I, Gibb S (2006) A comparison of low-cost biosorbents and commercials orbents for the removal of copper from aqueous media. J Hazard Mater 137:198-206

Daping S, Dafang Z, Dong J, Jingying F, Qiao W (2015) Integrated Health Risk Assessment of Heavy Metals in Suxian County, South China. Int J Environ Res Public Health 12:7100-7117

Davarnejad R, Panahi P (2016) Cu (II) removal from aqueous wastewaters by adsorption on the modified Henna with $\mathrm{Fe}_{3} \mathrm{O}_{4}$ nanoparticles using response surface methodology Sep. Purif Technol 158:286-292

David OM, Oluyege AO (2014) Effect of Open Refuse Dumpsite on the Quality of Underground Water Used for Domestic Purposes in Ado-Ekiti, Nigeria-A Public Health Awareness Study. Journal of Environment \& Ecology 5(2):1-12. https://doi.org/10.5296/ jee.v5i2.6241

Deshmukh KK (2013) Ground water quality evaluation with special reference to nitrate pollution in the Sangamner area, Ahmednagar district, Maharashtra, India, pp. 1-164, London: Water Pollution XI, 79, WIT Transactions on Ecology and the Environment.

Ejiogu BC, Opara AI, Nwofor OK, Nwosu EI (2017) Geochemical and Bacteriological Analyses of Water Resources Prone to Contamination from Solid Waste Dumpsites in Imo State, Nigeria. Journal of Environmental Sciences and Technology 10(6):325-343

Ganiyu SA, Badmus BS, Olurin OT, Ojekunle ZO (2018) Evaluation of Seasonal Variation of Water Quality using Multivariate Statistical Analysis and Irrigation Parameter Indices in Ajakanga area, Ibadan. Nigeria Applied Water Science 8:35. https://doi. org/10.1007/s13201-018-0677-y

Gowrisankar G, Ramachandra C, Sudha RR, Vetrimurugan E, Saravan D, Karthikeyan B, Usha A, Lakshmann E (2017) Chemical, Microbial and Antibiotic Susceptibility Analyses of Groundwater after a major Flood event in Chennai. Scientific Data 4:170135. https://doi.org/10.1038/sdata.2017.135

Jachimowski A (2017) Factors Affecting Water Quality in Water Supply Network. Journal of Ecological Engineering. 18(4); 110-117. http://dx.doi.org/https://doi.org/10.12911/22998993/ 74288

Kafadar K (1982) The efficiency of the Biweight as a robust Estimator of Location. J Res Natl Bur Stand 88(2):105-116

Kayode OT, Okagbue HI, Achuka JA (2018) Water Quality Assessment for Groundwater around a Municipal Waste Dumpsite. Data in Brief 17:579-587. https://doi.org/10.1016/j.dib.2018. 01.072

Magdalena W, Komorowska-Kaufman M, Pruss A, Rzepa G, Bajda T (2019) Removal of Heavy Metals and Metalloids from Water Using Drinking Water Treatment Residuals as Adsorbents: A Review. Minerals 9:487. https://doi.org/10.3390/min9080487

Mahadevaiah MS, Yogendra K, Mansour S, Abdul G, Suresha MS, Sathish MA, Nagendrappa G (2007) A Simple Spectrometric Determination of Phosphate in Sugar Cane Juice, Water and Detergent Samples. E-journal of Chemistry 4(4):467-473

Ojo AO, Olurin OT, Ganiyu SA, Badmus BS, Idowu OA (2020) Hydro-geochemical assessment of an open dumpsite in a basement complex of Abeokuta, Ogun State. Southwestern Nigeria Arabian Journal of Geosciences 13:620. https://doi.org/10.1007/ s12517-020-05651-w 
Olagunju E, Badmus O, Ogunlana F, Babalola M (2018) Environmental Impact Assessment of Waste Dumpsite Using integrated Geochemical and Physico-Chemical Approach: A Case Study of Ilokun Waste Dumpsite, Ado-Ekiti, Southern Nigeria. Civil Engineering Research Journal. 4(2); 001-013. http://dx.doi. org/https://doi.org/10.19080/CERJ.2018.04.555631

Onesmus NS (2019) Physico-Chemical and Bacteriological quality of water sources in rural settings. A case study of Kenya, Africa. Scientific African 2. http://dx.doi.org/https://doi.org/10.1016/j. sciaf.e00018

Palamuleni L, Akoth M (2015) Physico-Chemical and Microbial Analyses of Selected borehole water in Mahikeng, South Africa. Int J Environ Res Public Health 12(8):8619-8630. https://doi. org/10.3390/ijerph120808619

Press WH, Flannery BP, Teukolsky SA, Vetterling WT (1992) Numerical Recipes in FORTRAN: The Art of Scientific Computing, 2nd edn. Cambridge University Press, Cambridge, England, p 697

Radulescu C, Dulama ID, Stihi C, Ionita I, Chilian A, Necula C, Chelarescu ED (2014) Determination of Heavy Metal Levels in Water and Therapeutic Mud by Atomic Absorption Spectrometry. Roman Journal of Physics 59(9-10):1057-1066

Rezaei A, Hassani H, Tziritis E, Fard M, Seyedeh B, Jabbari N (2020) Hydrochemical characterization and evaluation of groundwater quality in Dalgan basin. SE Iran Groundwater for Sustainable Development 10:100353. https://doi.org/10.1016/j. gsd.2020.100353

Ruqia N, Muslim K, Muhammad M, Hameed UR, Naveed UR, Surrya S, Nosheen A, Muhammad S, Mohib U, Muhammad R, Zeenat S (2015) Accumulation of Heavy Metals (Ni, Cu, Cd, $\mathrm{Cr}, \mathrm{Pb}, \mathrm{Zn}, \mathrm{Fe})$ in the Soil, Water and Plants and Analysis of Physico-Chemical Parameters of Soil \& Water collected from Tanda Dam Kohat. Journal of Pharmaceutical Science and Research 7(3):89-97

Sandu M, Lupascu T, Tarita A, Goreacioc T, Turcan S, Mosanu E (2014) Method for Nitrate Determination in Water in the Presence of Nitrite. Chemistry Journal of Moldova. General, Industrial and Ecological Chemistry. 9(2); 8-13.

Standard Organization of Nigeria (SON, 2015) Nigerian Standard for Drinking Water Quality. Nigerian Industrial Standard. NIS-554-2015.

Sugirtharanb M, Rajendran M (2015) Groundwater Quality near Municipal Solid waste Dumping site at Thirupperumthurai. Batticaloa The Journal of Agricultural Sciences 10(1):21-28
Tomasz A (2017) Application of the Huber and Hampel M-Estimation in Real Estate Value Modeling. Geomatics and Environmental Engineering 11(1):15-23. https://doi.org/10.7494/ geom.2017.11.1.15

U.S. Environmental Protection Agency (EPA, 2003) Drinking Water Advisory: Consumer Acceptability Advice and Health Effects Analysis on Sodium. Office of Water (4304T), Health and Ecological Criteria Division, Washington, DC 20460. EPA 822-R03-006. http://epa.gov/safewater/ccl/pdf/sodium.pdf (accessed April 22, 2020)

Ullah R, Malik RN, Qudir A (2009) Assessment of groundwater contamination in an industrial city, Sialkot, Pakistan. Afr J Environ Sci Technol 3(12):429-446

Wagenet L, Mancl K, Sailus M (1995) Home Water Treatment. Northeast Regional Agricultural Engineering Service, Cooperative Extension. NRAES-48. Ithaca, NY.

Walton WC (1970) Groundwater Resource Evaluation, Pp. 620-664, New York, USA: McGraw Hill.

Wongsasuluk P, Chotpantarat S, Siriwong W, Robson M (2014) Heavy metal contamination and human health risk assessment in drinking water from shallow groundwater wells in an agricultural area in Uban Ratchathani province. Thailand Environ Geochem Health 36:169-182

World Health Organization (WHO, 2017) Guidelines for drinkingwater quality: fourth edition incorporating the first addendum. Geneva. Licence: CC BY-NC-SA 3.0 IGO.

Yidana SM, Banoeng-Yakubo B, Akabzaa TM (2010) Analysis of groundwater quality using multivariate and spatial analyses in the Keta basin, Ghana. J Afr Earth Sc 58:220-234. https://doi. org/10.1016/j.jafrearsci.2010.03.003

Young E, Timi T (2014) Determination of Metals in Pepper by Flame Atomic Absorption Spectroscopy. International Journal of Biological and Chemical Sciences 8(6):2891-2895

Zieneldien T (2018) Determination of Hardness of Various Water Samples. http://researchgate.net/publication/328630002 (accessed April 27, 2020).

Publisher's Note Springer Nature remains neutral with regard to jurisdictional claims in published maps and institutional affiliations. 